資料：

\title{
山口県における献血者 $\mathrm{HCV}$ 抗体陽性率の検討
}

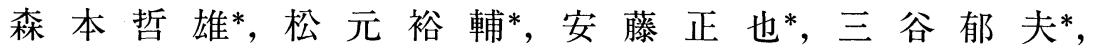 \\ 小西知 已*, 岡 崎幸 紀*
}

\begin{abstract}
山口県赤十字血液センターからの資料をもとに, 山口県に抢ける献血者の HCV 抗体陽性率を検 討した。C100- 3 抗体の測定には，「第 1 世代」が使用された。1989年11月から1990年12月までに献 血を执こなった，14万6792名を対象とすると， HCV 抗体陽性率は県平均が1.01\%であった。 HCV 抗体陽性率が $3 \%$ を越光た地域は 4 町あり, その中で, ある町は $22.0 \%$ と極端に高い陽性率を示し た。このような, HCV 抗体陽性率の地域差を解明するためには, 今後さらに研究が必要と思われる。
\end{abstract}

\section{(1)山口県 (2)献血者 (3) HCV 抗体陽性率 (4)地域差}

\section{緒言}

1988年米国の Chiron 社により血液関連非 A 非 B 型 肝炎ウィルスの遺伝子の断片が発見され(1)，C型肝炎 ウィルス (HCV) と命名されると共に, C 100-3抗体 の測定が可能となった2)。我が国では1989年より, 日赤 の献血者に招いてC 100-3抗体によるスクリーニング が開始され，献血者の約 $1.15 \%$ に陽性であることが判 明した ${ }^{3)}$ 。筆者は山口県赤十字血液センターから資料 を提供していただき，山口県に打ける献血者の HCV 抗体陽性率を検討した。C100-3抗体の測定には「第 1 世代」4)が使用された。な拉，1992年 2 月からは「第 2 世代」5)が導入されている。

\section{研究方法および成績}

1989年11月から1990年12月までに献血をおこなっ た, 14万6792名を対象とすると, HCV 抗体陽性率は県 平均が $1.01 \%$ であった。これは全国平均とほぼ同じ数 值である。山口県下で献血者の HCV 抗体陽性率が $3 \%$ を越えた地域は，O町 $22.0 \%, \mathrm{H}$ 町 $5.50 \%$, K町 $5.23 \%, \mathrm{~T}$ 町 $4.51 \%$ であり, O町が極端に高い陽性率 を示した。昭和50年度に山口県赤十字血液センターが, 山口県下の献血者に抢ける HBs 抗原陽性率の分布を 検討した。それによれば，O町の HBs 抗原陽性率は $0.5 \%$ 以下で極めて低い。

\footnotetext{
* 周東総合病院内科

（受付：1994年 2 月 14 日）
}

表 1 は, 1991年度の山口県下に扣ける献血者の $\mathrm{HCV}$ 抗体陽性率を，性別招よび年齢別に検討したも のである。男性と女性では陽性率はほぼ同じであり, 男女とも陽性率は年齢と共に上昇している。表 1 を用 いて男女の陽性率について, 有意差の検定を行ったが, 有意差は認められなかった。表 2 には男女の合計を示 した。表 2 を用いて，各年齢間の陽性率について，有 意差の検定を行った。その結果を表 3 に示すが，各年 代間に有意差を認めた。

次に, O町の献血者について, 年齢別に $\mathrm{HCV}$ 抗体陽 性率を検討した。その結果を表 4 に示す。陽性率は県 平均と比較して，各年代とも極端に高い。

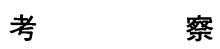

O町のよらに極端に HCV 抗体陽性率が高い地域の 存在については, 日本各地で報告されている ${ }^{6 \sim 8)}$ 。信州 大学のグループ6)は慎重ながら, 地域独特の針治療や, 医療機関での感染等が複合的に関与し，C型肝炎多発 地域を形成したと予測している。また，一針一筒以前 の予防接種が原因とする説もある。しかし，HCV 抗体 陽性率の極端な地域差が, これらの学説によって説明 できるか否か疑問が残る。

筆者らが行った, 地域検診に打ける肝機能異常例 (ZTT の上昇と, GOT と GPT の両者または一方の み上昇している例。ただし, 手術歴のある症例は除外 した。)の頻度を， $\mathrm{O}$ 町とそれに隣接するA町とで比較 してみた。A町に怙ける献血者の HCV 抗体陽性率は, $1 \%$ 未満である。O町に抢ける受診者は男性 97 例，そ 
表 1。献血者に抢ける HCV 抗体陽性率

\begin{tabular}{|c|c|c|c|c|c|c|}
\hline & 男 & 性 & & 女 & 性 & \\
\hline 年 & 検 査 数 & 陽性者数 & 陽 性 率 & 検 査 数 & 陽性者数 & 陽 性 率 \\
\hline $16 \sim 20$ (歳) & 14,629 (人) & 25 (人) & $0.17(\%)$ & 17,661 (人) & 35 (人) & $0.20(\%)$ \\
\hline $21 \sim 30$ & 17,680 & 86 & 0.49 & 14,479 & 76 & 0.52 \\
\hline $31 \sim 40$ & 19,342 & 172 & 0.89 & 8,941 & 74 & 0.83 \\
\hline $41 \sim 50$ & 15,639 & 173 & 1.11 & 8,932 & 124 & 1.39 \\
\hline $51 \sim 60$ & 7,107 & 179 & 2.52 & 5,704 & 153 & 2.68 \\
\hline $61 \sim$ & 1,171 & 70 & 5.98 & 913 & 16 & 1.75 \\
\hline 合 & 75,568 & 705 & 0.93 & 56,630 & 478 & 0.84 \\
\hline
\end{tabular}

表 2．男女の合計（年齢別）

\begin{tabular}{|c|c|c|c|c|}
\hline 年 & 齢 & 検 查 数 & 陽性者数 & 陽 性 率 \\
\hline $16 \sim 20$ & （歳） & 32,290 (人) & 60 (人) & 0.19 (\%) \\
\hline $21 \sim 30$ & & 32,159 & 162 & 0.50 \\
\hline $31 \sim 40$ & & 28,283 & 246 & 0.87 \\
\hline $41 \sim 50$ & & 24,571 & 297 & 1.21 \\
\hline $51 \sim 60$ & & 12,811 & 332 & 2.59 \\
\hline $61 \sim$ & & 2,084 & 86 & 4.13 \\
\hline 合 & 計 & 132,198 & 1,183 & 0.89 \\
\hline
\end{tabular}

表 3. 各年齢間の陽性率の検定

\begin{tabular}{|l|l|l|l|l|l|}
\hline $16 \sim 20$ 歳 & $21 \sim 30$ 歳 & $31 \sim 40$ 歳 & $41 \sim 50$ 歳 & $51 \sim 60$ 歳 & 61 歳 \\
\hline $16 \sim 20$ 歳 & $\mathrm{p}<0.01$ & $\mathrm{p}<0.01$ & $\mathrm{p}<0.01$ & $\mathrm{p}<0.01$ & $\mathrm{p}<0.01$ \\
\hline $21 \sim 30$ 歳 & $\mathrm{p}<0.01$ & $\mathrm{p}<0.01$ & $\mathrm{p}<0.01$ & $\mathrm{p}<0.01$ \\
\hline & $31 \sim 40$ 歳 & $\mathrm{p}<0.01$ & $\mathrm{p}<0.01$ & $\mathrm{p}<0.01$ \\
\hline & $41 \sim 50$ 歳 & $\mathrm{p}<0.01$ & $\mathrm{p}<0.01$ \\
\hline & $51 \sim 60$ & $\mathrm{p}<0.01$ \\
\hline
\end{tabular}

表 4. O町の献血者に扮ける HCV 抗体陽性率

('91年 4 月～' 92 年 6 月)

\begin{tabular}{|c|c|c|c|c|c|c|c|c|c|}
\hline & \multicolumn{3}{|r|}{ 性 } & \multicolumn{2}{|c|}{ 女 } & 性 & \multicolumn{2}{|c|}{ 合 } & 計 \\
\hline 年 齢 & 検査数 & 陽生者数 & 陽性率 & 検查数 & 陽性者数 & 陽珄率 & 検査数 & 陽性者数 & 陽性率 \\
\hline $16 \sim 20$ (訾) & ow & ow & $\begin{array}{ll}0 & (0)\end{array}$ & $3 \omega$ & $0 \omega$ & $0 \quad \%$ & $3 \omega$ & $0 \omega$ & $\begin{array}{ll}0 & (\%)\end{array}$ \\
\hline $21 \sim 30$ & 20 & 0 & 0 & 25 & 3 & 12.0 & 45 & 3 & 6.7 \\
\hline $31 \sim 40$ & 46 & 8 & 17.4 & 15 & 2 & 13.3 & 61 & 10 & 16.4 \\
\hline $41 \sim 50$ & 13 & 4 & 30.8 & 35 & 4 & 11.4 & 48 & 8 & 16.7 \\
\hline $51 \sim$ & 40 & 13 & 32.5 & 27 & 3 & 11.1 & 67 & 16 & 23.9 \\
\hline 合 計 & 119 & 25 & 21.0 & 105 & 12 & 11.4 & 224 & 37 & 16.5 \\
\hline
\end{tabular}

の5ち肝機能異常例は11例 $11.3 \%$ ，女性293例中 23 例 $7.8 \%$ でった。A町に拈ける受診者は男性121例，そ のらち肝機能異常例は 3 例 $2.5 \%$, 女性 279 例中 4 例 $1.4 \%$ であり，O町はA町と比較して男女とも約 5 倍の 肝機能異常例を認めた。このように HCV 抗体陽性率 が高い地域と, 低い地域が近接して存在するといら事 実をどう説明すればよいのか, 今後の研究が必要と思 われる。

\section{結語}

(1)山口県下で1989年11月から1990年12月までに献血を 扣こなった，14万6792名を対象とすると, HCV 抗体陽 性率は県平均が1.01\%であった。

(2) HCV 抗体陽性率が $3 \%$ を越えた地域は 4 町あり, その中で，ある町は $22.0 \%$ と極端に高い陽性率を示し
た。

(3)このような, HCV 抗体陽性率の地域差を解明する ためには，今後さらに研究が必要と思われる。

最後に本研究の資料を提供していただいた，山口県赤十字血液 センターに深謝する。

\section{文献}

1) Choo $\mathrm{QL}$, et al ; Isolation of a cDNA clone derived from a blood borne non-A, non-B hepatitis genome. Science $244: 359-362,1989$

2) Kuo G, et al ; An assay for circulating antibodies to a major etiologic virus of human non-A, non-B hepatitis. Science $244 ; 362-364,1989$

3 ) Nishioka K: Hepatic C virus infection in Japan. Gastroenterol Jpn 26 (Suppl 3) : 152-155, 1991

4) 倉井清彦, 他: HCV 抗体の定量測定々臨床応用. 肝臓 31 : 
$826-827,1990$

5 ) 飯野四郎, 他：第二世代 HCV 関連抗体測定キット HCV・ EIA II の検討. 医学々薬学 $26 ： 87-95,1991$

6) 田中栄司, 他：長野県一山村の非 A 非 B 型肝炎多発地域に拉 ける疫学調查一特に HCV 抗体陽性率について. 肝臓 32 ： $98-99,1991$
7 ）荒牧环己，他：猿島肝炎における長期追跡保存血清からみた HCV 抗体の臨床的意義. 肝臟32：125-130：1991

8 ) 時田 元, 他：非 A 非 B 型肝炎が多発する一山村に扣ける C $100-3$ 抗体, $\mathrm{CP}-9$ 抗体, $\mathrm{CP}-10$ 抗体执よび GOR 抗体の 血清疫学的調查. 肝蔵32：1093-1100, 1991

\title{
HCV Antibody Positive Rates of Blood Donors in Yamaguchi Prefecture
}

\author{
Tetsuo MORIMOTO*, Yusuke MATSUMOTO*, Masaya ANDO*, \\ Ikuo MITANI* and Yukinori OKAZAKI*
}

The HCV antibody positive rates of blood donors were studied in Yamaguchi Prefecture. C100 -3 antibody was examined by the method of the 1st generation. The subjects were 146, 792 people who donated blood from Nov. 1989 to Dec. 1990. The average positive rate was 1.01\% in Yamaguchi Prefecture. The positive rates of more than $3 \%$ were registered in four towns. In one town out of these four, the average positive rate was $22.0 \%$ It was extremely higher than the other three towns. Further study will be required to elucidate such regional differences in the HCV positive rate in the prefecture.

* Department of Internal Medicine, Shutou Hospital, Yanai, Japan 